\title{
The Spaces of Citizenship: Mapping Personal and Colonial Histories in Contemporary Italy in Igiaba Scego's La mia casa è dove sono (My Home is Where I Am)
}

\author{
Eleanor Paynter \\ Department of Comparative Studies, The Ohio State University, \\ Columbus, Ohio, USA
}

\begin{abstract}
As Italy has changed from emigration country to immigration destination, the growing body of literature by migrant and second-generation writers plays an important role in connecting discourses on race and national identity with the country's increasing diversity, its colonial past, and its contemporary spaces. This essay explores the 2010 memoir La mia casa è dove sono (My Home is Where $I \mathrm{Am}$ ) by Igiaba Scego, the daughter of Somali immigrants, as life writing that responds to these changing demographics and, more broadly, to the migration trends affecting contemporary Europe. In Scego's memoir, the narrator integrates her Roman identity and Somali background and, in this telling, returns forgotten or ignored colonial history to Italian public discourse and public space. Scego's voice as a second-generation Italian writer of color has the potential to challenge dominant discourses of race and national identity which perpetuate the precarity of migrants in Italy. By narrating the personal and historical in the context of Roman monuments and neighborhoods, $L a$ mia casa è dove sono challenges and redefines who can be "Italian," modeling a more inclusive Italianità. I discuss the text in terms of its use and revision of collective memory and its development of a narrative "I" that claims a position within a collective identity while challenging the exclusionary tendencies of that very group.
\end{abstract}

Keywords: Italian colonial history, citizenship, migration, second generation, memoir 
Igiaba Scego's 2010 memoir La mia casa è dove sono (My Home is Where I $A m)^{1}$ is a life narrative that responds to changing demographics in contemporary Europe, and Italy in particular. ${ }^{2}$ The memoir enables the narrative "I," a woman of color and the child of Somali migrants, to claim both physical and discursive space in Italy, a country with colonial ties to Somalia and with few guaranteed routes to citizenship for migrants and their children. In this age of migration, with the increasing number of refugees entering Europe, Scego's voice as a second-generation Italian writer of color has the potential to challenge dominant discourses of race and national identity which perpetuate the precarity of migrants in Italy, in part by rendering citizenship difficult, if not impossible, to attain. By framing the personal and historical in the context of Roman monuments and neighborhoods, Scego's memoir challenges and redefines who can be "Italian." The self constructed through her narration models a more inclusive "Italianità" by integrating Scego's Roman identity and Somali background as the narrative returns collectively forgotten or ignored colonial history to Italian public discourse and public space.

In La mia casa è dove sono, Scego, who was born in Rome in 1974, recounts her first eighteen years growing up in Italy as both Italian and Somali, a complicated hybridity given Italy's colonization of Somalia through the 1950s. Scego herself has citizen status in Italy and is an activist for migrant and refugee rights. ${ }^{3}$ She writes, therefore, from a now relatively stable position, yet also from an intimate familiarity with the struggles of those living in diaspora. Her work challenges the exclusion of people of color and colonial history from the dominant constructs of national identity in Italy. ${ }^{4}$ Central to the construction of a narrative self in the memoir are multiple kinds of memory-personal memories of the narrator's childhood in Italy and of visits to Somalia, and familial memories of life in Mogadishu—as well as a critique of forgetting, which appears here as Italy's collective amnesia for its own colonial history. In addition, the memoir exemplifies what Caren Kaplan has discussed as a politics of location which decenters dominant narratives by emphasizing local, material experience, rather than metaphor, and which requires attention to "concerns about race and imperialism" (Kaplan 167).

My discussion takes its cue from the sequence of Scego's memoir, which moves from a family gathering through more integrated historical and familial narratives, to the final chapter, "Being Italian for Me," which focuses on individual identity and connects directly with the reader. In what follows, I briefly contextualize the memoir within Italy's recent designation as an immigrant destination. I then explore the reconfiguration of national identity through second-generation memoir by considering how Scego layers the personal, historical, and geographical to 
construct a narrative "I," by relying on a kind of "memoire involontaire" (Benjamin), and how this layering can be read as a kind of cognitive mapping (Jameson). In general, my position is motivated by the notion that autobiographical processes and practices offer, as Smith and Watson have demonstrated, "occasions for negotiating the past, reflecting on identity, and critiquing cultural norms and narratives" (Inter/Faces 9). They also offer a way for the autobiographical subject to claim a position within a group whose collective identity is structured to exclude her.

\section{IMMIGRATION AND "LETTERATURA DELLA MIGRAZIONE"}

Italy's change of status in the early 1980s from emigration country to immigration destination, as well as the last decade's increased migrant arrivals, have brought racial, religious, and linguistic diversity to the country that remains relatively new for many in the predominantly white mainstream. ${ }^{5}$ Scego's parents arrived in 1969-1970, shortly before these shifts. The foreign-born population has grown rapidly in recent decades. In 1991, approximately 350,000 documented non-European foreigners lived in Italy; in 2010, the year Scego's memoir was published, that number had reached 4.5 million (ISTAT "La Presenza Straniera"; ISTAT "Cittadini Non Comunitari"). ${ }^{6}$ Demographic changes in Italy echo similar shifts across Europe; distinguishing the Italian situation are a combination of factors, including the diverse nationalities of entering migrants, the lack of jus solis, or birthright citizenship policy, and the absence of public discourse about the country's colonial history. ${ }^{7}$

Responses by European governments and media to the surge in migrant arrivals since 2015 have generally perpetuated the perception of immigration as a crisis. This view has certainly been echoed by Italian mainstream media and by politicians who have spoken out against inclusionary policies and have fought proposed legislation to enact jus solis citizenship in Italy, maintaining instead the country's policy of jus sanguinis, or inherited citizenship (Polchi) ${ }^{8}$ These debates, which have largely failed to historicize contemporary migration, have a potentially significant impact on recent migrants, as well as on the children of immigrants, who now constitute the country's first sizeable second generation.

Within discourses of race and national identity, the diverse, growing body of Italian "letteratura della migrazione," or literature by first- and second-generation Italians, represents an important set of voices. ${ }^{9}$ Scholars including Lidia Curti, Graziella Parati, and Sandra Ponzanesi have pointed to its role in giving voice to marginalized groups and in challenging understandings of Europe and its nation-states as necessarily or 
implicitly white or otherwise homogeneous. In performing this work, many of the narratives within letteratura della migrazione focus on the struggles of migrants, sometimes from former colonies, who encounter racism and violence as they attempt to connect with communities and create a life for themselves in Italian cities (Curti and Lombardi-Diop and Romeo)..$^{10}$

Such narratives often address what Caterina Romeo has noted as the problematic absence of race from the discourse of Italian identity: "Race-historically a constitutive element in the process of Italian national identity-has 'evaporated' from the cultural debate in contemporary Italy as a result of the necessity to obliterate 'embarrassing' historical events" (Romeo 222). Italy's colonial campaigns in Libya, Eritrea, Ethiopia, Somalia, and Albania are studied minimally, if at all, in schools and are generally absent from public discussions of twentieth-century history, ignored in part as linked with the "embarrassing" history of the fascist era, but also not taken up in discussions of the nineteenth century, which included the first colonial campaigns (Medi). ${ }^{11}$

Scego's work is notable for its incorporation of colonial history and the ways in which she links that history with contemporary Italy. Her most recent novel Adua (2015), for example, follows the story of a Somali man working for an Italian colonial general in the 1930s and, in the present day, his daughter who has lived in Rome since the 1970s. In her memoir, Scego addresses the problem of collective amnesia directly. In the first chapter, the narrator notes:

In many [other countries] after World War Two there was discussion, squabbling, the views exchanged were bitter and impetuous; societies interrogated themselves about imperialism and its crimes; studies were published; the debate influenced literary production, research, film, music. In Italy, instead, silence. As if nothing had happened. (18)

She calls attention to this silence-and challenges it-as part of her story, presenting it to the reader as she introduces herself and her family. Scego has witnessed the growth of the migrant population in Italy during her lifetime and has reflected on the legal, cultural, and historical dimensions of these changes in journalistic writing and activism, in addition to her literary pursuits. ${ }^{12}$ The memoir can thus be understood as one instantiation of her social, political, and personal work.

\section{MAPPING MEMORY: THE POLITICS OF LOCATION}

As Sandra Ponzanesi and Daniela Merolla explain in the introduction to their anthology Migrant Cartographies, given the relationship between 
European nations' colonial enterprises and contemporary political and economic turmoil in former colonies, migration in the twenty-first century is "a literal and metaphorical transition in space but also a translation in time" (3). Symbolically, the presence of migrants from former colonies in the lands of former colonizing powers makes that history present; migration from East Africa to Italy recalls the colonial conquest of and eventual retreat from that region, bringing the past into the contemporary moment. It is no surprise, in turn, that Scego's memoir focuses so explicitly on memory.

La mia casa è dove sono begins with an act of collective remembering: the narrator and her siblings sit down to map what they recall of Mogadishu, the city from which their parents fled during Siad Barre's 1969 coup d'état. ${ }^{13}$ Scego, who has spent time in Somalia but grew up in Italy, has difficulty seeing herself in this map; it does not quite represent her or her origins. In what might be considered a coaxing scene, or the impetus inspiring the narrative (Smith and Watson Reading Autobiography 50-52), Scego shows the map to her mother, who remarks, "It's not enough... That city on the map is not your city... Let's say that it is in a certain sense. But at the same time it's not" (29). Scego becomes determined to complete the sketch for herself.

Memory here functions as an act of recall that reconstructs forgotten history and, sometimes, forgotten or no-longer-existing spaces. Scego's mapping of Somali colonial history, for example, relies on her parents' memories and her own recollections from summer visits in the 1980s, before the civil war. The Somalia she describes is one she constructs through memory and imagination. As she writes when first attempting to plot places in Mogadishu: "I'd never been to the restaurants, but when I was little I had dreamt of them as elegant places" (27). The question "Does this city exist?" first asked by Scego's nephew Deq and then posed by Scego herself, becomes a complicated one, prompting the narrator to reflect on the extent to which Mogadishu is indeed her city, and on the effects of recent conflict: "The war destroyed everything. Only rubble. Now there are are different things in those spaces. Not the ones on the map. Those exist only in memories, in old photos, in stories, on websites in black and white" (28). In her attempt to map remembered places along with "forgotten" histories, Scego assembles a narrative "I," a self that emerges through this act of telling. In this way, the author participates in what Inderpal Grewal describes as the "many narratives by women of color around the world that propose and enact new forms of locating themselves within societies" (Grewal 234). Scego constructs a self for readers, in other words, by integrating these narratives in the context of the city of Rome. 
The chapters that follow can be read as a version of this map: Scego's birthplace of Rome anchors the text, but Mogadishu and Rome become intertwined through her personal narration and, importantly, through their histories. All but the first and last chapters are named for specific monuments or neighborhoods in Rome (e.g. the Stele of Axum, Trastevere) and offer a brief travel-guide-like description of the object or place before moving into personal and historical narrative.

Located in such a way, each chapter moves between a geographical position and the personal and historical memories that it recalls and represents. Given the centrality of the initial site of each chapter to the narrative that unfolds in its pages, Smith and Watson's notion of sites as both "occasional and locational" is relevant here in interpreting the layers of memory associated with particular places (Reading Autobiography 69). "Locational narration" serves, in fact, as an organizing principle for the memoir: narratives are arranged not chronologically, but according to their associations with specific sites.

Through Scego's telling, one Italian piazza might contain, simultaneously, a single memory, a family history, and East African history, as well, locating and prompting the autobiographical narrative as "a dense and multilayered intersection of the temporal and the geographic" (Smith and Watson Reading Autobiography 74). Scego's narrative challenges the binaries often assigned to diasporic communities, "disrupt[ing] the home/ abroad and the margin/center constructs for more complex positionings" (Grewal 235). The story of her uncle's assassination in the Xamar Ja-Jab area of Mogadishu, for example, appears in a chapter named for the obelisk that once stood near Rome's Circus Maximus (Scego 86-88). The brief chronicling of her father's upbringing begins with his attendance at a Nat King Cole concert in Rome (36). Not only does her narrative complicate notions of diaspora, it also maps race onto Italian history, and in fact onto the capital city. The memoir counters dominant narratives that, as Fatima El-Tayeb has discussed, place "racialized minorities... outside of the national and by extension continental community" (El-Tayeb xvii).

One of the ways in which La mia casa è dove sono challenges the exclusionary realities of Italy's dominant collective identity is through a politics of location, a method which Caren Kaplan has documented from its emergence in the work of Adrienne Rich to its subsequent applications in contemporary transnational feminist studies and critical race theory. As a feminist practice "interrogating and deconstructing the position, identity, and privilege of whiteness" (Kaplan 139), a politics of location aims to claim space for marginalized groups. In relation to Scego's memoir, I follow Kaplan's description of the method as investigating "the productive tension between temporal and spatial theories of subjectivity" (138). 
Rather than celebrate or prompt nostalgia, Kaplan suggests that a politics of location problematizes dominant narratives. The memoir's historical situatedness prompts inquiry into the events and geographies that have shaped the present.

The chapter beginnings, which introduce the monument or neighborhood named in the chapter title, comprise one of the clearest examples of Scego's politics of location. With a narrative voice that is informative, personal, and self-conscious, these travel-guide-like sections function to establish the narrator's authority as Roman. That same authoritative voice introduces more than just the history one might read in a textbook or guide. The opening to the "Piazza Santa Maria Sopra Minerva" chapter, for example, blends the personal and the historical: "[The piazza] is a refuge for whoever is sad or just wants to reflect... The church that dominates the piazza (and which shares its name) was built on the site of an ancient temple erroneously attributed to the goddess Minerva Calcidica [Greek Minerva]" (53). When the narrator goes on to explain that thieves stole the church organ, "then burned it" (54), she reconfigures the church as not only a place for pilgrims or tourists, but a monument for women in diaspora or who have been displaced: "On my map I draw a string of hearts. For all those who are finding voice despite a thousand obstacles. For my mother who managed to find her voice when it was necessary. And for my writing, which today owes so much to those courageous voices" (54). This commemoration, enacted by reconceptualizing the Santa Maria Sopra Minerva church space to stand for a more diverse set of experiences, constitutes an act of claiming space through narration. Indeed, for a Muslim narrator in a Catholic space, this gesture takes on potentially more significance, though the narrator's own religious background or practice does not feature as a significant subject in the memoir.

Here, the politics of location aligns with what migration scholars such as Iain Chambers have suggested as the need for a new and flexible "mode of thinking... that is open to the prospect of a continual return to events, to their re-elaboration and revision" (Chambers 3). The realities of migration force communities and scholars to question histories, borders, and identity categories, and to consider new forms of knowledge. By mapping family narratives and colonial histories onto contemporary Rome, Scego participates in this knowledge construction, creating room for voices that might otherwise have few outlets or audiences. By claiming the church as a monument for women, she also implicitly brings women in diaspora into the church's existing symbolism as an Italian monument. The authority with which she recounts the official history-dates, purpose, context-encompasses, too, the personal stories she weaves into it, expanding what fits within that "Italian" narrative. 


\section{COLLECTIVE FORGETTING AND RACIALIZED MIGRATION}

Because colonial history has been for the most part excluded from Italian mainstream memory, Scego's mapping has a more than personal function: it is an act of recall for the collective, revising the notion of "acts of personal remembering" as "fundamentally social and collective" to suggest how individual remembering can affect available public memories (Smith and Watson Reading Autobiography 21). Scego's hybridity as Somali-Italian and as a second-generation daughter allows her both to be a member of this national community and to be aware, in another sense, of what it lacks.

In his discussion of contemporary migration and cultural identity, Chambers explains that the "retelling, re-citing and re-siting of what passes for historical and cultural knowledge depend upon the recalling and remembering of earlier fragments and traces that flare up and flash in our present 'moment of danger' as they come to live on in new constellations" (3). These flashes of memory remind us that the collective past has a bearing on the present moment, and that our capacity for taking in our circumstances depends on an awareness of our present context as historically situated. In Benjaminian terms, the relationship between past and present emerges through involuntary memory (memoire involontaire) to connect the individual to the collective. In his "Motifs on Baudelaire," Benjamin explains that, through involuntary memory, "where there is experience in the strict sense of the word, certain contents of the individual past combine with material of the collective past" (113). A fuller understanding of the present and one's relation to the collective depends on the possibility of even unconsciously recalling history, and without more complete historical narratives, people are unable to process the changes that Benjamin refers to (via Freud) as the shock or stimuli of the present day. For Benjamin, the inability to connect the experiences of stimuli with historical contexts has potentially traumatic consequences for individual subjects (115). At a population level, detachment from historical realities may enable practices of marginalization.

In Italy, the collective amnesia involved in the shift from the colonial period to the present-day age of migration has led to a loss of experience that perpetuates the exclusion of people of color from the dominant Italian collective imaginary. Scego's narrator both expresses and is motivated by critical awareness of this discursive gap:

In Italy some roads have African names. In Rome there's even the 'African quarter'. In Viale Libia, a Roman will tell you, there are lovely clothing stores, you can get some nice items. But then? Then nothing. They go to 
Viale Libia to buy a sweater. They live in Via Migiurtinia ${ }^{14}$ and they kiss in Viale Somalia. But they ignore colonial history. It's not their fault: in school it's not like they teach you these things. We were good, they tell you, we built bridges and fountains. The rest is ignored, because it's not taught. (27)

The cues abound, in other words, even in street names, but the memory is absent.

Scego's parents' relationship to Italy, which also influences how she constructs her map, dates back to the colonial period. Though Italian popular understanding often associates a limited account of colonial history with the Fascism of the 1920s and 1930s, Italy sought territory in Africa as early as the 1860s and eventually took control in Libya, Eritrea, Ethiopia, and Somalia (Ben-Ghiat and Fuller xiv-xviii). ${ }^{15}$ In Somalia, areas of which have been ruled, at different times, by British, Ethiopian, French, and Italian governments, Italian and British colonizers eventually split the country in two, with Italy controlling the southern part (Abdi 331). In her memoir, Scego describes the colonial period through the memories of her father, Ali Omar Scego: "During colonialism, the Italians never wanted to create Somali leadership groups. Consider, my daughter, we could only study through the fourth grade"; further education was prohibited by law (42). Continued economic and political trouble in Somalia can be traced back in great part to the colonial period, and racism and segregation in Italy, as elsewhere in Europe, are directly tied to colonial relationships (Romeo 222-223).

Despite having "lost" its colonies in World War II, Italy was granted administrative control of Somalia from 1950 to 1959, when the UN determined that the country needed "to prepare... for independence" (Abdi 332). Scego's father was part of a group of men brought to Rome and trained by Italian administrators to become political leaders in a liberated Somalia. ${ }^{16}$ Yet after trusteeship, Somalia saw only a decade of governance under Italian-trained ministers. Historian Robert Hess noted as early as 1966, just six years after independence, that trusteeship had not brought the country to self-sufficiency (Hess 195). After trusteeship, Italy allowed some Somalis to enter as "visitors," and in 1969, when the coup d'état led by Siad Barre prompted Scego's parents to flee, Italy, whose culture and language were familiar, made sense as a destination. ${ }^{17}$

Scego presents herself not as a diasporic writer in the sense of someone longing for a homeland from which she has been displaced, but as a fully hybrid subject, a Roman writer proud of her city and a Somali who finds her country, as she writes in the memoir's dedication, "everywhere it is" ("Alla Somalia, ovunque essa sia"). The book's title (My Home is Where I $\mathrm{Am}$ ) and dedication point to a kind of mobility-home as something we 
carry, rather than something we lose or leave behind, a notion discussed extensively in the work of Stuart Hall and others (Hall 226). I would argue that the concept of home as portable has particular resonance in diasporic spaces in which citizenship is not an option for all residents, or when the new place of residence, in this case Italy, does not accept the migrant as a full member of society. By presenting to readers a "self" who does claim full membership, Scego recognizes and challenges this exclusion.

In terms of the relation between individual memory and the collective past, one of the most provocative chapters is "The Stele of Axum," which refers to the stele ${ }^{18}$ originally from the ancient holy city of Axum in Ethiopia, brought to Rome by Mussolini's troops in 1937 (Scego 71). Scego recounts the story of the stele's first patron, the Queen of Sheba, who, according to legend, traveled to Jerusalem and fell in love with King Solomon but decided to return home. On her return journey, she stopped to rest under the stele. "She was carrying King Solomon's son and the stele was the first to learn the joyful news" (74). Scego's narrative "I" perceives this role of confessor/confidant as symbolic of the stele's long history. "Oh stele," she asks, shifting to apostrophe, "How many stories could you tell us?" (74). The histories and geographies that converge in the stele, uncountable though they may be, connect at least Israel and Ethiopia, Italy and East Africa, and modern-day Italians and Ethiopians with the stele's life on two continents. The contention surrounding historical narratives of Ethiopia as colonized or colonizer, including decades of conflict between Ethiopia and Somalia, make this particular association stand out in the memoir. ${ }^{19}$

Scego's connection to the stele has changed; ten years ago, it stood in the piazza, a looming reminder-for Scego, who would now remind readers-of Italy's violent conquest of East Africa. In 2005, after much negotiation, the monument was finally returned to Ethiopia (BBC News). Now, the author's connection-what might be described as her memoire involontaire-is triggered by its absence. "Every time I pass through Piazza di Porta Capena I fear the oblivion" (91), she says, referring to her own affective experience as it is prompted by the empty plinth. Because she has always associated the piazza where the stele once stood with her grandfather and the uncle who was assassinated, now the empty space sparks a double sense of loss. The shock of the absent monument brings up these personal and public pasts in a visceral way as the narrator passes through the piazza.

Residents of Rome regularly pass by any of a number of monuments to colonialism; obelisks, statues, and inscriptions that recall ancient and modern conquests are scattered throughout this urban geography, from 
Roman Imperial victory monuments such as Trajan's Column in the Forum, to the Piazza dei Cinquecento, the square near Termini station which commemorates the 500 colonial soldiers who died during a decisive 1887 battle in Eritrea and which is widely misunderstood as representing the Renaissance ("cinquecento" can also refer to the 1500s; see "Igiaba" Termini TV). But if members of the dominant group can only recognize these landmarks within a forgotten or fragmented history, then they are unlikely to associate the celebrated cityscape with realities of migration. Within this metropolis are the communities with heritage in former Italian colonies. In Rome, a stroll along nearly any of the streets leading to Termini, the main train station, now takes the pedestrian past a large ethnic food market and cafés where Somali and Eritrean migrants and their Italian-born children chat at outdoor tables. "No other neighborhood knew how to pamper or slap you like Stazione Termini," explains the memoir's narrative "I," noting how the station's role as a gathering space for migrants made it both a community center and a constant reminder of their struggles (101). As Lombardi-Diop and Romeo write in the introduction to their anthology Postcolonial Italy: Challenging National Homogeneity, "Migrants to Italy both from former Italian colonies and from other formerly colonized territories are today articulating the shifts of meaning in the processes of signification that subtend postcoloniality" (10). The very presence of migrants, in other words, potentially triggers memoire involontaire, yet without historical context, that articulation may not resonate with members of the dominant culture.

Moreover, it may not be recognized as relevant to discourses of race. El-Tayeb has discussed racism in Europe as related to ethnicization that not only excludes people of color from the national imaginary, but also "permanently defines ethnicized citizens as "migrants" (El-Tayeb xiv). Identifying acts of oppression and marginalization as racist and discriminatory, while also countering the exclusionary nationalist tendencies behind them, requires fuller understanding of the relationship between the present and this underdiscussed history. ${ }^{20}$ Migrant and second-generation writing "exposes the sense of uneasiness generated for (white) Italians by the association of blackness with Italianness" (Lombardi-Diop and Romeo 10). Scego's memoir challenges that discomfort by making colonial and diasporic realities part of the Italian narrative.

In her 2007 discussion of migrant writing by women in Italy, Lidia Curti problematizes how colonialism has, in fact, entered dominant cultural narratives:

Despite the flowering of recent research... there is little awareness of the essential role that the colonial discourse has played in the formation of a 
national identity. The cultural components of the colonial experience have left a long trail in the popular imaginary, through songs, images, stereotypes, caricatures, slogans that have all contributed to racist attitudes in Italy. It is easy to forget that the hybridity of contemporary immigrants includes us [white Italians]. (63)

Here hybridity refers to that collective negotiation of culture and identity that occurs as a response to colonial domination (Bhabha 175) and which implies bidirectional change: Italian culture was shaped by colonial encounters. Contemporary migration both recalls this history and is, simultaneously, met with racist responses that resist coming to terms with incomplete historical memory. The centrality of racialization to the colonial enterprise, in other words, remains cemented in cultural artifacts. ${ }^{21}$ Yet current discourses that deny citizenship and even entry to migrants are related to the racist practices that legitimized colonialism (and led to those artifacts) and today fail to acknowledge a more complete colonial history-one that considers the position of colonial subjects and people of color-as Italian. Today it is possible to participate in this "trail" of artifacts without understanding its racist foundations or how its effects are reiterated with continued use. Contemporary migration and its representation in literature challenge this practice.

\section{LOCATING THE SELF THROUGH COGNITIVE MAPPING}

Ultimately, Scego's memoir moves toward an ending that is both intimate and inclusive. She closes the book reflecting on her own position in the narratives she has told and includes the reader in the map she has created. One way to understand Scego's remapping of the city is as a transcript of her self-positioning within what Fredric Jameson calls "the totality" of her world. In other words, she uses the pages of her memoir to have the narrative "I" spell out how she has, in Jameson's terms, cognitively mapped her "social relationship to local, national and international class realities" (91). Applying Jameson's cognitive mapping to the memoir seems, at first, too easy an approach: her memoir is a map and is prompted by the act of mapping. Yet it is worth remembering that Jameson himself leads readers to the concept via Kevin Lynch's work on alienation in the city (89) and the cartographic analogies of the compass and globe (90).

In Jameson's original essay, cognitive mapping represents one strategy for individuals to locate themselves and understand their relation to society in the fragmented and flattened, or unhistoricized, reality of postmodernism, or late capitalism. Postcolonial migration highlights this fragmentation, as movement across borders reveals the lack of full contextualization of the present. ${ }^{22}$ Avtar Brah echoes these points in her 
essay about Southall, England, as a destination for migrants from former British colonies: "Knowing [the self] ... [requires] recognizing our constitution as 'ourselves' within the fragments that we process as knowledge" (273). Locating the self among fragments, she says, is the only way we can attempt to comprehend the positions of others. Contemporary Italy, one could argue, lacks a coherent, defining narrative (Ponzanesi 98), and La mia casa è dove sono, as an example of cognitive mapping, is one such orienting gesture. "I've tried here to recount scraps of my own story," the narrator explains. "Of my journey. Scraps because memory is selective. Scraps because memory is like a shattered mirror... And my map is the mirror of these years of change" (159-160). These scraps or shards are the fragments of a postcolonial reality that requires mapping in order to be understood as at all coherent.

The memoir's penultimate chapter, "Stadio Olimpico," illustrates how Scego locates herself in a fractured reality. Named for Rome's football stadium, the chapter includes the 1991 onset of civil war in Somalia. Scego is then in school in Rome, and her mother has gone to Somalia to visit relatives and investigate the possibility of moving back. One of the connections Scego must map, then, is between civil war, her own position in Italy, and her mother's absence. She does this, in the remarkably brief space of eight pages, by integrating accounts of the problems that plagued her at that time: news about relatives killed or missing and the anxiety of not hearing from her mother become part of an everyday life that already includes the anxieties of adolescence (136-138). As these anxieties multiply, Scego develops bulimia: "It was around the seventh month [of not hearing from her mother] that I started to vomit. Or maybe already the sixth" (142). She describes her bulimia in terms of fragmentation and absence: "It was then that something broke inside of me. Pleasure was out of the question" (143). This sense of precarity, of limbo or transience brought on by her mother's disappearance, affects her connection with her Italian classmates: "For those two years I faked an appearance of normality with the world," she writes (145).

At home, she relates her response to these anxieties to lyrics by a famous singer: "It was just like in that Vasco Rossi song, me alone in the bathroom and the whole world outside" (147). ${ }^{23}$ In this subtle but significant move, when she seems at her most vulnerable, she identifies through the lyrics of an Italian pop culture icon. While the narrator describes these school years in some detail as divided between performing normalcy and fearing for her family, these passages are notably short, moving toward the moment of her mother's return to Rome. With her mother back, her bulimia stops. Significantly, Scego does not close the chapter with this intimate domestic moment, but by moving into the chapter's particular setting: the narrator and a cousin head to a Roma match at the stadium, cheering on their team for an afternoon she describes as "bellissimo" (148). 
These fragments of seemingly disparate experiences or aspects of identity serve a constructive function for Scego, who is motivated by the fragments to assert individual and cultural agency (Whitlock 18). This example challenges arguments put forth by scholars such as Rey Chow, who has problematized the past as "not always readily available" to the writer of color or ethnic writer, who uses writing to protest her/his marginalization and claim recognition, only to be "confine[d] and immobilize[d]" by that very act (Chow 146, 152). There is a kind of helplessness in what Chow calls "the fragmented nature of ethnic writing" (146) which is absent from Scego's memoir. Rather than linger on the incompleteness of public memory or on her own knowledge of the past as limiting or marginalizing, Scego uses the fragments to build her own narrative. In this way, the memoir can be read both as a response to the need to locate her position in the fragmented reality of postcolonial migration and as a demonstration of that act of locating. By narrating across the gaps of public memory, Scego not only locates herself within the Italian context but, in effect, remaps that very context for the reader as one in which she is a full participant.

In the re-envisioned totality, the many histories and spaces that affect the author are interlocking: Italian history as it occurred in East Africa and as it involved Scego's family; Somali history that, shaped by colonialism, brought this community to Rome; the Roman monuments that recall colonial campaigns; Mogadishu, where Italian-designed fountains and cinemas recall the cities of the former colonizer. Through "the coordination of existential data (the empirical position of the subject) with unlived, abstract conceptions of the geographic totality" (Jameson 90), Scego secures her position as both Italian and Somali and offers this version to the reader in the "intersubjective exchange" of autobiographical narration (Smith and Watson Reading Autobiography 13).

Fundamental to Scego's memoir is her ultimate focus on both life narrative and identity itself as ongoing processes. Near the end of the final chapter, after a brief litany of possible identity labels-"I'm Italian, and not. I'm Somali, and yet not. A crossroads. A fork in the road" (158)—she determines that her identity is found "by recounting the journey taken up to this moment" (159), in other words in the preceding narrative. Citing Italian and Somali history, as well as her own upbringing, she states, "I am the product of this interwoven chaos" (159). Her sense of self emerges through the act of writing, of constructing this narrative for readers, a notion which echoes Stuart Hall's explanation of diasporic identities not as fixed in dislocation but as "constantly producing and reproducing themselves anew, through transformation and difference" (235).

The book's final line returns to the map and addresses the reader for the first time overtly: "It's not a coherent map. It's central but also peripheral. It's Rome, but also Mogadishu. It's Igiaba, but it's also you" (160). 
This is the narrator's call to experience: for readers to see themselves on the map, in the histories Scego has woven into her own narrative, and, perhaps, for readers to map their own positions within the totality.

\section{CONCLUSION}

Whether Scego's readers will perceive their own positions as existing within this remapped reality is not something Scego can control, but it is certainly one of her aims. As that final "you" suggests, Scego constructs her own story by drawing on and revising collective memory not only to locate herself, but to challenge members of the white mainstream to reconsider their own understanding of and relationship to the past.

This invitation is to some extent limited by the book's marketing. After initial publication by Rizzoli press in Milan, another edition was printed by Loescher Editore, a press which produces materials for primary and secondary school curricula and for Italian language learning. This version, marketed for high school classes, contains numerous footnotes, a historical afterward, and discussion questions, geared toward a readership of young Italian citizens and, perhaps, migrants who are studying the language. These paratexts serve to further contextualize a memoir which is itself focused on contextualization. In presenting the text, however, the Loescher edition does little to promote the memoir's challenge to national identity and, in fact, risks undermining it; the foreword, by critic Goffredo Fofi, begins by identifying the author not as Italian or SomaliItalian, but as "Somali, born in Rome" (Scego, Loescher edition, 3).

In a sign of growing readership, Scego's most recent novel, Adua, has been featured at several national literary festivals, though still under the label of migrant writing, sometimes qualified as "letteratura italiana migrante" ("Programma 2015," emphasis added). With the gradually increasing circulation of work by second-generation writers, Scego's audience may continue to expand, and the national literary market may increasingly include works and authors who are currently labeled as "migrant."

In Scego's case, life narrative as a process and testament (Eakin $\mathrm{x}$ ) enables her to claim both physical and discursive space, in turn demonstrating for the broader Italian public how essential collective memory is in confronting the potential Benjaminian "shocks" of contemporary migration. By layering history and urban space, the memoir suggests how recalling and connecting to a more complete collective memory might influence public discourse about race and national identity. Given the lack of public historicization of the current migration situation across Europe, as well as the continued lack of citizen status for many second- and third-generation Italians, the matter of how to affect discursive practices on race and civil 
rights is especially urgent. The question "who is Italian" is one iteration of the national identity question being asked around the globe, as migration becomes recognized as not a momentary phenomenon, but a fact of global societies. How it gets taken up is a critical matter in Europe where, despite EU-level asylum regulations, each country still maintains its own unique set of policies and processes in response to the high numbers of arriving asylum seekers. If they survive the journey, refugees in Italy must not only deal with the vagaries of resettlement and legal status, but also worry about their children born within Italian borders who have no guarantee of permanence. Scego's memoir is an example of narrative that complicates general understandings of history and geography to urge dialogue that acknowledges forgotten pasts and their impact on present-day circumstances for all Italians, including those entering the country at this very moment.

\section{ACKNOWLEDGMENTS}

I would like to thank Eugene Holland and Julia Watson for critical feedback on this essay. Thanks also to colleagues in Lynn Itagaki's summer writing seminar for insightful comments on earlier drafts.

\section{BIBLIOGRAPHY}

Abdi, Ali A. "Education in Somalia: History, Destruction, and Calls for Reconstruction." Comparative Education 34.3 (1998): 327-340.

Alba, Richard and Roxane Silberman. "Decolonization Immigrations and the Social Origins of the Second Generation: The Case of North Africans in France." International Migration Review 36.4 (2015): 1169-1193.

"Albachiara." Angolo Testi, 31 May 2016, www.angolotesti.it/V/testi_canzoni_vasco_rossi_1563/testo_canzone_albachiara_41210.html.

BBC News. "Obelisk Arrives Back in Ethiopia." BBC News 19 Apr. (2005).

Ben-Ghiat, Ruth and Mia Fuller, eds. Italian Colonialism. New York: Palgrave MacMillan, 2005.

Benini, Stefania. "Tra Mogadiscio e Roma: le mappe emotive di Igiaba Scego." Forum Italicum 48.3 (2014): 477-494.

Benjamin, Walter. "Some Motifs in Baudelaire." Charles Baudelaire: A Lyric Poet in the Era of High Capitalism. New Left Books, 1973. 107-154.

Bhabha, Homi. The Location of Culture. New York: Routledge, 1994.

Boahen, A. Adu. African Perspectives on Colonialism. Baltimore: Johns Hopkins University Press, 1987.

Bonifazi, Corrado, Frank Heins, Salvatore Strozza, and Mattia Vitiello. "Italy: The Italian Transition from an Emigration to Immigration Country." IDEA Working Paper 5. March 2009.

Brah, Avtar. "The Scent of Memory: Strangers, Our Own and Others." Eds. Avtar Brah and Annie E. Coombes. Hybridity and its Discontents: Politics, Science, Culture. New York: Routledge, 2000.

Caponio, Tiziana. "( $\operatorname{Im})$ Migration Research in Italy: A European Comparative Perspective." Sociological Quarterly 49.3 (2008): 445-464. 
Chambers, Iain. Migrancy, Culture, Identity. New York: Routledge, 2001.

Chow, Rey. The Protestant Ethnic and the Spirit of Capitalism. New York: Columbia University Press, 2002.

Curti, Lidia. "Female Literature of Migration in Italy." Feminist Review 87 (2007): 60-75.

"Disegno di legge." Senato della Repubblica. www.senato.it/japp/bgt/showdoc/17/DDLPRES/940816/index.html. Accessed 22 Nov. 2016.

"Donne e cittadinanza." RAI Storia, 2014, www.raistoria.rai.it/articoli/donne-e-cittadinanza/20304/default.aspx. Accessed 4 May 2016.

Eakin, Paul John. How Our Lives Become Stories. Ithaca: Cornell University Press, 1999.

El-Tayeb, Fatima. European Others: Queering Ethnicity in Postnational Europe. Minneapolis: University of Minnesota Press, 2011.

Grewal, Inderpal. "Autobiographic Subjects and Diasporic Locations: Meatless Days and Borderlands." Grewal and Kaplan. 231-254.

Grewal, Inderpal and Caren Kaplan, eds. Scattered Hegemonies: Postmodernity and Transnational Feminist Practices. Minneapolis: University of Minnesota Press, 1994.

Hall, Stuart. "Cultural Identity and Diaspora." Ed. Jonathan Rutherford. Identity: Community, Culture, Difference. Chadwell Heath: Lawrence and Wishart, 1990. 222-237.

Hess, Robert. Italian Colonialism in Somalia. Chicago: University of Chicago Press, 1966.

"Igiaba e il colonialismo nascosto di Termini." Termini TV, 5 Oct. 2015, termini.tv/mondayspecials/igiaba-e-il-colonialismo-nascosto-di-termini/. Accessed 5 April 2016.

ISTAT. "La presenza straniera in Italia negli anni '90.” Istituto nazionale di statistica (ISTAT), 1995.

ISTAT. "Cittadini non comunitari: presenza, nuovi ingressi e acquisizioni di cittadinanza." Istituto nazionale di statistica (ISTAT), 2015.

ISTAT. "Non-EU citizens: presence, new inflows and acquisition of citizenship." Istituto nazionale di statistica (ISTAT), 29 September 2016. www.istat.it/en/archive/190679.

Jameson, Fredric. "Postmodernism, or the Cultural Logic of Late Capitalism." New Left Review 1.146 (1984): 53-92.

Kaplan, Caren. "The Politics of Location as Transnational Feminist Critical Practice." Grewal and Kaplan. 137-152.

Khouma, Pap. Io, venditore di elefanti. Milano: Garzanti, 2006.

"La mia casa è dove sono." Loescher editore, www.loescher.it/dettagliocatalogo/O_30270/Lamia-casa-e-dove-sono. Accessed 1 Nov. 2016.

Lombardi-Diop, Cristina and Caterina Romeo, eds. Postcolonial Italy: Challenging National Homogeneity. Palgrave, 2012.

Medi, Marina. "La memoria del colonialismo italiano tra censura e rimozione." Strumenti 58 feb. 2012.

Polchi, Vladimiro. "Ius Soli, Altro Passo Avanti Sì Al Voto Tra Le Polemiche." La Repubblica, 9 Oct. 2015, ricerca.repubblica.it/repubblica/archivio/repubblica/2015/10/09/iussoli-altro-passo-avanti-si-al-voto-tra-le-polemiche16.html?ref=search. Accessed 10 Dec. 2015.

Ponzanesi, Sandra and Daniela Merolla. Migrant Cartographies: New Cultural and Literary Spaces in Post-Colonial Europe. Lanham: Lexington Books, 2005.

Ponzanesi, Sandra. "Post-Colonial Women's Writing in Italian: A Case Study of the Eritrean Ribka Sibhatu." Northeast African Studies 5.3 (1998): 97-115.

"Programma 2015." Festival Letteratura, 1 Nov. 2016, www.festivalletteratura.it/files/programma2015.pdf.

Quijano, Aníbal. "Coloniality and Modernity/Rationality." Cultural Studies 21.2-3 (2007): 168-178.

Romeo, Catarina. "Racial Evaporations: Representing Blackness in African Italian Postcolonial Literature.” Lombardi-Diop and Romeo. 221-236. 
Scego, Igiaba. La mia casa è dove sono. Milano: Rizzoli, 2010.

Scego, Igiaba. La mia casa è dove sono. Torino: Loescher, 2012.

Scego, Igiaba. "Bloccata la costruzione del mausoleo fascista di Affile." Internazionale, 22 Apr. 2013, archivio.internazionale.it/news/italia/2013/04/22/zingaretti-blocca-la-costruzione-del-mausoleo-fascista-di-affile. Accessed 1 Nov. 2016.

Scego, Igiaba. Adua. Milano: Giunti, 2015.

Smith, Sidonie and Julia Watson, eds. Inter/Faces: Women, Autobiography, Image, Performance. Ann Arbor: University of Michigan Press, 2002.

Smith, Sidonie and Julia Watson. Reading Autobiography: A Guide for Interpreting Life Narratives. 2nd ed. Minneapolis: University of Minnesota Press, 2010.

United Nations High Commissioner for Refugees (UNHCR). "High Commissioner's Global Initiative on Somali Refugees." http://www.unhcr.org/pages/527b8f7d6.html. Accessed 2 May 2016.

United Nations High Commissioner for Refugees (UNHCR). "Refugees/Migrants Emergency Response-Mediterranean." data.unhcr.org/mediterranean/country.php?id=105. Accessed 20 Nov. 2016.

Whitlock, Gillian. Soft Weapons: Autobiography in Transit. Chicago: University of Chicago Press, 2007.

\section{ABOUT THE AUTHOR}

Eleanor Paynter is currently pursuing her PhD in the Department of Comparative Studies at the Ohio State University. She works in the areas of literature and migration, focusing on life writing, oral history, and refugee narratives. At present, she studies narratives by and about asylum seekers in Italy as part of a larger interest in changing notions of identity and belonging in a broader European context. She also serves as an editor for the Amsterdam-based literary \& arts journal Versal.

\section{NOTES}

1 This book has not yet been published in English translation; I have translated the excerpts that appear in the present paper for the purposes of this discussion. Unless noted, page citations refer to the original Rizzoli edition.

2 Following Smith and Watson, I adopt the terms "life narrative" and "memoir" to reflect the processes of self-referential life writing as ongoing processes, as opposed to the more fixed, canonized notion of "autobiography" (Reading Autobiography 2-4).

3 In an interview for RAI Storia, Scego explains how lucky she feels that her parents insisted on completing necessary procedures to obtain Italian citizenship for themselves and Scego when she was around 10 years old. Otherwise, she says, she might not have been able to obtain citizen status when older, as current law insists on continuous residency ("Donne e cittadinanza").

4 On Italy's fragmented yet exclusionary national identity, see Ponzanesi (98-99).

5 Internal migration also has a troubled history, including discrimination against SouthNorth migrants following industrial changes after World War Two (Bonifazi et al. 7-8).

6 As of Fall 2016, Morocco, Albania, and China are the countries of origin for the majority of registered non-EU migrants in Italy (ISTAT "Non-EU Citizens"). Refugees and asylum 
seekers from former colonies have continued to arrive to Italy in 2016; as of November 2016, $12 \%$ of refugees arriving via the Mediterranean were from Eritrea and 5\% were from Somalia (UNHCR "Refugees/Migrants").

7 Whereas a large number of immigrants to France and Germany, for example, came through guest worker programs (from Morocco and Turkey, respectively; see Alba and Silberman 2015), newcomers to Italy have always represented a range of origins, some with direct colonial ties (e.g. Somalia, Ethiopia, Albania), and others without (e.g. China, the Philippines) (Bonifazi 18-25).

8 At the time of writing, the Italian government is debating two versions of jus solis, which they label "ius soli temperato" and "ius culturae" (Polchi, "Disegno di Legge").

9 "Letteratura della migrazione" is sometimes also referred to as "letteratura migrante."

10 Pap Khouma's autobiographical book Io, venditore di elefanti (I Was an Elephant Salesman) (Khouma), is often cited as one of the earliest Italian migrant works (Romeo 225). In the last decade, Italian migrant literature has shifted from a male-dominated category to one noted for its strong female voices, including, for example, Cristina Ali Farah, Gabriella Ghermandi, and Scego.

11 In fact, Ethiopia is often included in lists of Italian colonies, but many accounts resist this label, using the term "occupation" rather than "colonization" when referring to Ethiopia, in part because Italy only stayed in control there from 1935 to 1941 (Boahen 55).

12 Scego writes regularly for the news and culture periodical Internazionale, for example, and works with the G2 (second generation) organization.

13 For a more extensive discussion of this scene and of Scego's mapping of Mogadishu, see Benini.

14 "Migiurtinia" is Majerteen, the Somali Sultanate.

15 Mussolini also sought to colonize Albania (Ben-Ghiat and Fuller 2).

16 As Scego notes in the memoir, Siad Barre was part of this group.

17 While it is beyond the scope of this article to document the current political situation, it is important to note that Barre's 22-year rule and its subsequent collapse have meant the continued flight of Somalis (see UNHCR).

18 A stele looks like an obelisk but usually has a rounded top.

19 Though outside the scope of the present paper, the example of the Ethiopian stele brings up important questions concerning memory and identity that are worth noting here, including whether an Ethiopian monument would resonate similarly for other Somalis or Somali-Italians. For Scego, it seems, family history includes her grandfather's work as a translator for the Italian general who led forces in Somalia and in Ethiopia, so the connection is, once again, historical but also quite personal (Scego "Bloccata").

20 As in many European contexts, marginalization in Italy has until recently been addressed in terms of nationality or religion, rather than race. Racial and ethnic data in Italy are limited in part because of citizenship laws and reliance on the all-encompassing category of "foreign" (Caponio).

21 While it is beyond the scope of this article to address the construction of race through colonialism, "coloniality of power" has been discussed by scholars including Aníbal Quijano, who has explained its function "with the social category of 'race' as the key element of the social classification of colonized and colonizers" (Quijano 171).

22 Because the memoir in question is a postcolonial work set in the land of the former colonizer, I do not apply Jameson's work on Third World literature to the present discussion, nor do I consider Scego's work to be representative of this category.

23 In the song "Albachiara," Rossi sings, "Tu sola dentro la stanza/e tutto il mondo fuori" ("You alone in the room and the rest of the world outside") ("Albachiara"). 